\title{
What future for postwar Bosnia?
}

It is not too soon for the rest of Europe to begin preparing for the aftermath of the tragic warfare in ex-Yugoslavia; on the contrary, doing nothing now is a recipe for permanent calamity.

THREE years of warfare in ex-Yugoslavia have left a scar on the world's civility, and will almost certainly cause further harm before the fighting ends. For those who are most tragically afflicted, the people who live in the once-federated states and in Bosnia and Herzegovina in particular, the scars will not be healed for decades, until recollections of those who have been killed or maimed have faded. The worst outcome, not improbable, is that troubles like those besetting Northern Ireland for the past quarter of a century will become endemic in much of what used to be Yugoslavia. If and when peace is declared, there will be ample supplies and sources of munitions to give people the illusion that they can settle old scores without making things even worse. The temptation to follow that course will be strengthened by the way in which the community (at least in Bosnia and Herzegovina) has been confirmed in its three-way division by recent horrors.

The rest of Europe could not live with such a state of affairs without its own security being undermined. Already the reputation of the European Union or EU (and of its designated but still-theoretical military arm, the Western European Union) has been damaged by the failures of three years ago. The decision, at the insistance of Germany, to recognize Slovenia as an independent state made the breakup of the federation irreparable, but Western Europe's most prosperous states also too eagerly embraced the correct legal doctrine that one state cannot intervene in the domestic affairs of another as an excuse for doing very little. But short of military intervention, there is much that could have been done by political means (carrots as well as sticks) to make the rewards of inter-communal violence less attractive.

The dangers for the rest of Europe of chronic strife in the Balkans are easily foretold. Experience elsewhere has shown how local divisions are reflected internationally. At least some of the tension between Russia and the United States apparent in the past few weeks is, for example, directly attributable to a single air strike around Gorazde. (That the strike was ordered by the Secretary-General of the United Nations, an Egyptian, on the advice of his Japanese deputy in the field, and carried out by NATO aircraft in accordance with a resolution of the Security Council is relevant, but seems not to be so regarded.) Even if there is a formal settlement in ex-Yugoslavia, the risk that there will follow a trial of strength by proxy between backers of the three subcommunities must be very high.
The economic and social damage that has and will be done in ex-Yugoslavia must also be reckoned with. For a country whose exports consisted largely of the hospitality for which tourists paid, patterns established in the past three years of going elsewhere will persist. But who then, and with what resources, will rebuild those damaged houses and restore damaged farms to produce work? Especially if the United Nations embargo is itself maintained? There is all too real a danger that ex-Yugoslavia, already pauperized by the inflation that seems inseparable from warfare, will become a pauperized patch of poverty on the Southern rim of what is Western Europe. That would be insupportable.

But what can be done? The temptation to believe that it is too soon to be thinking constructively should be suppressed. Culturally and economically, ex-Yugoslavia is as much a part of the EU as, say, the Baltic States or the Slavic states of Central Europe, with all of which the EU is holding preliminary talks on eventual membership. It would be a carrot of sorts, and perhaps a powerful one, if the EU were to say that it seeks a way of dealing with ex-Yugoslavia and its parts, jointly or severally, on the same footing. More immediately, it would help if the rest of Europe followed the University of Warsaw in offering to help educate the cohorts of potential students who will otherwise be denied an education in exYugoslavia. Both these steps, and others, would cost money, but probably not as much as the Balkans will otherwise cost Western Europe.

\section{Instant legislation}

\section{A British Cabinet minister has been helping to highjack legislation for populist purposes.}

BRITAIN, which has traditionally boasted of its way of conducting parliamentary business in what it likes to call the 'Mother of Parliaments' (the House of Commons), appears to be falling apart in that connection as well as others. Last week, Mrs Virginia Bottomley MP, who is also the Secretary of State for Health in the British government, assisted in a plot to tag onto a much debated piece of legislation a populist and ill-considered prohibition of the use, in the treatment of infertility by in vitro fertilization (IVF), of ova from aborted fetuses. The merits of the prohibition apart, the case has all the hallmarks of the procedures in the US Congress by which 